Portland State University

PDXScholar

5-23-2013

How Old Regimes Help New Economic Growth

Bondon Kawamoto

Portland State University

Follow this and additional works at: https://pdxscholar.library.pdx.edu/honorstheses

Let us know how access to this document benefits you.

Recommended Citation

Kawamoto, Bondon, "How Old Regimes Help New Economic Growth" (2013). University Honors Theses.

Paper 28.

https://doi.org/10.15760/honors.25

This Thesis is brought to you for free and open access. It has been accepted for inclusion in University Honors Theses by an authorized administrator of PDXScholar. Please contact us if we can make this document more accessible: pdxscholar@pdx.edu. 


\title{
How Old Regimes Help New Economic Growth
}

\author{
By \\ Bondon Kawamoto
}

An undergraduate honors thesis submitted in partial fulfillment of the requirements for the degree of

Bachelor of Arts

in

University Honors

and

Economics

and

Japanese

Thesis Advisor

Hiro Ito

\section{Portland State University}

2013 


\section{Introduction}

Most people are more familiar with Japan's economic growth in the postWorld War II period but unfamiliar with the impressive growth that occurred around a century before. As impressive as Japan's postwar economic growth was, during the Meiji era (1868-1912) Japan also experienced high economic growth as well as rapid industrialization. Nonetheless, some commentators have overlooked the importance of the economic growth of the Meiji era (1868-1912), putting more emphasis on the post-war era economic growth of Japan ${ }^{1}$.

The word Meiji, however, carries with it far more than connotations of simple institutional reform. The Meiji era of Japan was indeed a time of transition as the country transformed from a secluded feudal state to a military power on par with the West. Furthermore, the beginning of the Meiji Era was a time of institutional reforms, but better said, it was a time of revolution as thousands were killed in pursuit of a new Japan; and it was this new Japan that entered into the industrial age. So, the Meiji era should be thought of as a time of revolution and change, but it should also be thought of as a time of rapid economic growth, as Japan began to challenge the existing Euro-centric world.

The Meiji period began with the transition of power from the Tokugawa family, who ruled from 1603 to 1868, to the Meiji Emperor, who ruled from 1868 to 1912, in what is known as the Meiji Restoration. Historically, in a revolution, the new regime moves forward, replacing the old regime with new institutions, governance and life styles. However, the Meiji Restoration, which occurred in Japan

\footnotetext{
${ }^{1}$ In Ohkawa and Rosovsky (1973), the authors refer to the Meiji era as "years of institutional reform [rather] than years of rapid economic growth." p. 9
} 
in 1868 , was different in many ways. While there was bloodshed and reform, not all of the ideals of the previous Tokugawa regime were destroyed. In fact, the Meiji government did quite the opposite of what one would imagine from a revolution and did not wipe out all of the Tokugawa practices and leaders. Instead of executing or banishing Tokugawa leaders, many of them were bestowed bureaucratic positions. Instead of destroying all Tokugawa institutions, the Meiji government left some institutions, such as the education system, in place. Through the implementation and usage of these people and institutions, the Meiji government was able to usher Japan into an era of substantial economic growth and industrialization, that was in retrospect as impressive as what was experienced by other Western imperial powers at the time.

It is the goal of this essay to further examine this phenomenon of an old regime helping a new regime, specifically the effects the Tokugawa regime had on the Meiji economy. Because the economic growth of the Meiji era was so substantial and vastly important for Japan's growth as a world power, it is important to understand how the nation was able to produce such high rates of economic growth. The theory behind the economic growth will be based on the Solow Growth Model2, which provides prediction of economic growth based on the assumption that capital and labor are used as inputs to produce income while technology affects its productivity. The focus of this essay is not to explain each cause of economic growth in Meiji Japan; much work on this subject has already been accomplished. Rather, this essay will seek to establish a connection between the Tokugawa regime and the

2 The Solow Growth model was created in the mid-1950's by Robert Solow who advanced the Harrod-Domar model. 
Meiji regime, discussing how the Tokugawa regime affected Meiji Japan and the economic effects therein ${ }^{3}$.

While the post-World War II era may appear impressive due to its robustness that led the economy to become one of the world's largest, we cannot overlook the Meiji economic growth, which paved the way for the industrialization of Japan and increased the nation's technological advancement. Without the Meiji economic growth, Japan would not have experienced the economic development in the post-World War II era in the way it did. The post-war growth occurred after the nation's infrastructure had been crippled by the devastation of the war and the nation was forced to start from square one. However, as Thorstein Veblen noted, technology is an "immaterial equipment 4 " that is more important than physical objects 5 . Hence, it should not be an exaggeration that the high economic growth and the rebuilding of Japan in the post-war era could occur heavily owing to the high economic growth the country experienced in the Meiji era and the nation building upon it with the economic system, bureaucracy and other governing systems, and social intellectual infrastructure, all of whose foundations were created in the Meiji era. Japan was able to recreate production facilities and other infrastructure and experience economic growth after World War II. In this essay, I argue that the flexibility the Meiji regime embraced was the key to the successful economic development, allowing the leaders to retain continuities from the Tokugawa regime,

${ }^{3}$ see Crawcour, 1974 for an earlier work on the transition between Tokugawa and Meiji.

${ }^{4}$ Veblen, Thorstein. Imperial Germany. New York, Augustus M. Kelley, 1915.

5 For more on Veblen's theory of the importance of technology, read Ken McCormick's commentary on Veblen's work in Veblen in Plain English in the chapter titled Technology. 
and enabling the Meiji leaders to import advanced technology from the European powers.

In section two, I will give a broad overview of the Meiji era economy, explaining its impressive performance and the characteristics of the growth in 1868 to 1912. In section three, I will explain the economic success of the Meiji economy from the perspective of the Solow Growth Model. In section four, I will discuss the Tokugawa era's legacy that shaped the Meiji era and aided the high economic growth by focusing on the Tokugawa education system and Tokugawa intellectual's outside curiosity with the West, which led them to adopt Western institutions and technology. In section five, I will conclude the essay.

\section{The Impressiveness of the Meiji Era Economy}

In 1868, when the Meiji era started, Japan was an agrarian nation, which had shut itself off from the outside world for more than two centuries. By 1912, however, Japan transformed itself from a reclusive feudal state into a world economic power. When the Tokugawa rule ended and Meiji rule succeeded the leadership in the 1860's and 1870's, Japan experienced economic chaos, and was afflicted by high inflation and stagnant economic growth. However, by the end of the

period, a series of reforms and stabilization measures were implemented, rebuilding the foundation of economic development. These reforms were supplemented by successful importation of technology spurring Japan into rapid economic growth. 
The reforms that occurred during the Meiji era drove Japan into an era of growth featuring an average GNP growth rate of $2.4 \%{ }^{6}$ from 1887 to 1913 , a number on par with the other western powers of the time such as the United States, which grew at $4.6 \%,{ }^{7}$ or England, which grew at $2.1 \%{ }^{8}$. Japan also averaged a per capita GNP rate of around 2\% in the Meiji period. Furthermore, Japan's growth rate of per-capita income, an oft-used measure of economic development, at the start of their modern economic growth period (1874-79) grew at higher rates than what Western nations experienced at the beginnings of their economic growth. Japan had a per-capita income rate of $2.9 \%$ compared to the United States (1834-43) at 1.6\%, Britain (1765-85) at $1.2 \%$ and Germany (1850-59) at $1.7 \%{ }^{9}$.

The economy of the previous regime, Tokugawa Japan, was based heavily on agriculture and the tertiary sector ${ }^{10}$. However, by the end of the Meiji period (1912), almost 50 years after the Meiji Restoration, the size of the manufacturing industry, as a percentage of net national product, had increased from $16 \%$ to $30 \%$ while the size of the agricultural industry had halved from $53 \%$ to $19 \%{ }^{11}$. While as a percentage of net national product, the agricultural industry halved, its size of

${ }^{6}$ Ohkawa, Kazushi. Analysis of the Japanese Economy. Shunjusha, 1962. in Nakamura, Takafusa. Economic Growth in Prewar Japan. Yale University Press, New York, 1983. p. 2

${ }^{7}$ Department of Commerce (U.S.). Historical Statistics of the United States, 1976. In Nakamura (1983). p. 2 ${ }^{8}$ Mitchell, B.R. European Historical Statistics. McMillan, 1975. In Nakamura (1983) p. 2

${ }^{9}$ Ito, Takatoshi. The Japanese Economy. 5th. Cambridge, MA: MIT Press, 1992. p. 16. Japan's data is from Kuznets, (1971).

${ }^{10}$ Nakamura, Takafusa. Economic Growth in Prewar Japan. Yale University Press, New York, 1983. p. 3

${ }^{11}$ Ohkawa, Kazushi; Takamatsu, Nobukiyo; and Yamamoto, Yuzo. National Income. Toyo Keizai Shimpo Sha, 1974. in Nakamura, p. 3 
production grew from about $\$ 1$ million to $\$ 8$ million in 1934 dollars due to the overall economic growth in the Meiji period. Both the manufacturing and the agricultural industries are important to a nation's economic growth and it is evident that both industries were wisely encouraged and invested in by the Meiji government ${ }^{12}$.

Japan's shifts in diplomatic policies around the Meiji Restoration also contributed to impressive growth in international trade. Since the early $19^{\text {th }}$ century, Russian, British and French traders had all inquired to trade with the Japanese but had only been met with a refusal ${ }^{13}$. Among the European powers, the Dutch, however, had been permitted to trade, though solely in Nagasaki, since the beginning of the $17^{\text {th }}$ Century ${ }^{14}$. Nagasaki had been the only port in Japan where interactions with foreigners, including the Dutch, Chinese and Korean, occurred during the Tokugawa Era ${ }^{15}$. However, this seclusion, called sakoku in Japanese, was not as strictly executed as one might think. Haga Toru writes: "For all the talk of seclusion, Japan was probably receiving more information from other countries than any other non-Western country of the time."16 In fact, the Dutch presence in Japan during the sakoku period had a great influence on many Japanese citizens who studied Western sciences through studying Dutch - these scholars were called the

\footnotetext{
12 Sharpe, p. 76

13 Gordon, Andrew. A Modern History of Japan: From Tokugawa Times to the Present. $2^{\text {nd }}$ ed. New York, Oxford University Press, 2009. p. 49

14 In the 1630's, when all Westerners were banned from Japan, the Dutch were allowed to remain in Japan because they did not have any Christian influence. 15 Pyle, Kenneth B. The Making of Modern Japan. 2nd e. Lexington, MA: D.C. Heath and Company, 1996. p. 58 Pyle writes: "Between 1635 and 1852 more than 5,500 Chinese ships came to Nagasaki."

16 Toru, Haga and Masakazu Yamazaki. "Reexamining the Era of National Seclusion," Japan Echo 19 (winter 1992), 73-75.
} 
Dutch scholars. In 1720, Tokugawa Yoshimune, a shogun who was interested in Western sciences such as astronomy, geography and watchmaking, eased seclusion edicts, allowing Western literature in Japan, as long as they were not Christian works ${ }^{17}$.

Such interactions with the world outside Japan later had significant political consequences. On July 8, 1853, Commodore Matthew Perry visited Japan in an attempt to create a trade treaty with the Japanese. While the Japanese did not want to begin trade with the Americans due to not only their xenophobic feelings, but also the terms ${ }^{18}$ that greatly favored the Americans, some Dutch living in Japan argued that the Japanese should acquire Western technologies so as to defend themselves against the Western powers. At that time, refusal of trade agreements would only lead to war $^{19}$. On March 31, 1854, the Treaty of Kanagawa was signed, opening Japan for trade with the United States. Similar treaties with other European powers such as France, England and Russia ${ }^{20}$ were signed in the following years. The start of commerce with the European and United States imperial powers was greatly controversial and divided the nation into two groups.

A kaikoku (open country) school was comprised of samurai who were familiar with Western knowledge and advanced technologies while a joi (expel the

17 Pyle, 1996. p. 58

18 The terms of the treaties Japan faced were so one-sided, they are often referred to as "unequal treaties." Under the unequal treaties, Japanese tariffs were placed under international control and import duties were fixed at low levels. An extraterritorial system was also established providing that foreign residents were subject to their own courts, not Japanese law (Pyle, 1996. p. 64).

19 Pyle, 1996. p. 60 The Dutch hoped to help Japan avoid a situation such as the Opium Wars occurring in China, where Britain forced trade on the Qing Dynasty from 1839-42 and 1856-60.

20 Gordon, 2009. p. 50 
barbarian) school was comprised of members against a foreign presence in Japan ${ }^{21}$. This conflict escalated when members of the joi school turned their attention from expelling foreigners to removing any kaikoku presence in Japan. Eventually, members of the joi school staged a coup ${ }^{22}$ leading to the end of the Tokugawa rule and the beginning of the Meiji era.

In the beginning of the Meiji era, Japan mostly exported food, tea, textiles and silk, but by the end of the Meiji period, the exportation of primary goods decreased and manufactured goods started accounting for a layer portion of exports. Despite the unequal treaties Japan faced, by 1905, about 50 years after it decided to open up to foreigners, Japan had emerged as a primary exporter of goods, such as textiles and silk, in East Asia. Such trends continued on into the following Taisho period $(1912-1927)^{23}$. The growth in heavy industry exports nearly tripled over the course of the Meiji era. Overall, Japanese exports increased from 52 million yen, or $6 \%$ of GNP in 1885 to over a billion yen, or $22 \%$ of GNP by $1912^{24}$. Through the period, Japan ran a minimal trade deficit, relying little on foreign debt, which meant the country was self-sufficient, despite its status as a developing nation ${ }^{25}$. Following their victory in the Sino-Japanese War (1894-95), the Japanese used the reparation they acquired from the Qing dynasty to further industrialization. The reparation

\footnotetext{
${ }^{21}$ Pyle, 1996. p. 60

${ }^{22}$ For more information on the Choshu-Satsuma alliance and the ousting of the Tokugawa regime, see Pyle, 1996. pp. 69-71.

${ }^{23}$ Export data in the last two sentences are found in M.E. Sharpe's Nation Building cited above.

${ }^{24}$ Ohkawa, Kazushi and Shinohara, Miyohei with Larry Meissner. Patterns of Japanese Economic Development: A Quantitative Appraisal. Yale University press, 1979. in Nakamura, p. 5

${ }^{25}$ Japan practiced self-sufficiency and avoidance of foreign debt in order to prevent itself from being colonized by the Western powers (Sharpe, p. 88).
} 
also allowed Japan to join the gold standard on October 1, 1897, which was believed to provide better access to Western markets ${ }^{26}$.

Japan further impressed the world when its Imperial Army defeated the Russians in the Russo-Japanese War (1904-05)27. Viewed as the underdog prior to both wars, Japan shocked the western powers by first defeating China, and then Russia as the first non-western nation to defeat a western nation militarily. The Japanese had emerged into the $20^{\text {th }}$ century a military power in the Pacific that was sustained by its robust, industrialized economy.

\section{The Solow Growth Model and the Meiji Era (1868-1912)}

To fully understand the effects of the Tokugawa regime on the Meiji era economy, it is necessary to understand the role technology plays in economic growth. According to the Solow Growth Model, an influential model that predicts economic growth, technology is one variable that directly affects an economy's productivity. The Solow Growth Model predicts that adding technology to an economy will raise the productivity of the economy and subsequently raise the output level. The effects of the Tokugawa regime on the Meiji regime were technological innovations; therefore I will use the Solow Model to frame the Meiji era economic growth.

\footnotetext{
${ }^{26}$ Metzler, Mark. Lever of Empire: The International Gold Standard and the Crisis of Liberalism in Prewar Japan. Berkeley: CA, University of California Press, 2006. p. 3 ${ }^{27}$ For more on Meiji militarism in relation to technology growth, see Yamamura (1977).
} 


\subsection{The Theory of the Solow Growth Model}

The importance of technology in the Meiji Era economy can be explained through the usage of the Solow Growth Model. The Solow model begins with the aggregate production function, which is a function of capital and labor, given by $\mathrm{Y}=\mathrm{F}(\mathrm{K}, \mathrm{N})$. Capital $(\mathrm{K})$ represents the sum of all plants, machinery and offices in the economy while labor $(\mathrm{N})$ represents the number of workers in the economy. The aggregate production function illustrates how much output $(\mathrm{Y})$ is produced for given quantities of capital and labor. The function works under the assumption of decreasing returns to capital and decreasing returns to labor. This means that

Figure 1

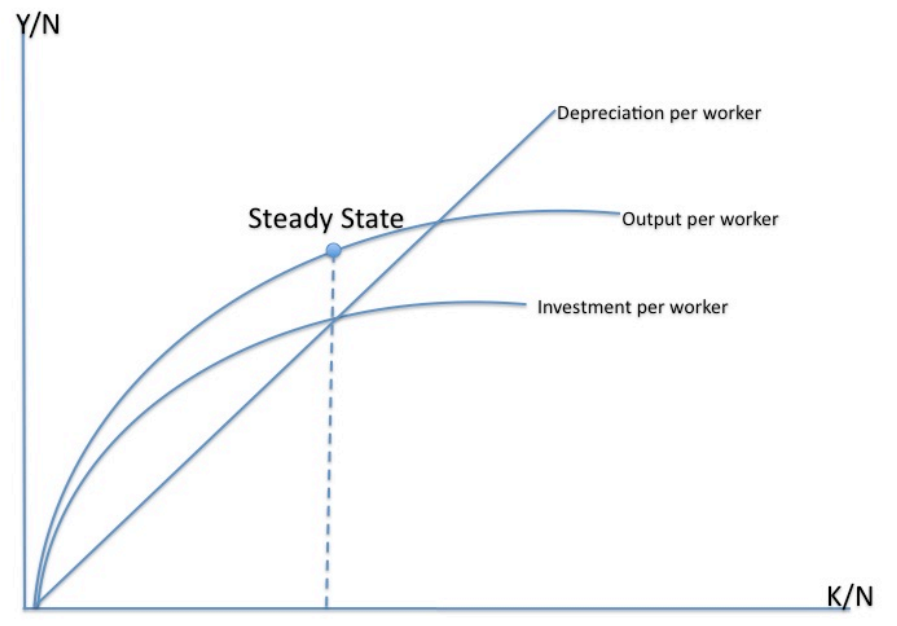

increases in either capital or labor will lead to smaller and smaller increases in output. This is illustrated by the flattening out of the production curve in figure 1 above, which shows that at low levels of output, an

increase in either capital or labor will create a relatively large increase in output while at high levels of output an increase in capital or labor will have a much smaller effect on output. The production function implies a simple relationship between output per worker $(\mathrm{Y} / \mathrm{N})$ and capital per worker $(\mathrm{K} / \mathrm{N})$. The relationship between these variables is shown by the upward sloping curve labeled "output per worker" in figure 1. Because the curve is a function of capital per worker, as a nation's 
capital per worker increases, the nation's output level increases as well. Adding capital per worker into an economy will lead to a high economic growth rate until the economy reaches the steady state. As the economy gets closer to the steady state, the growth rate slows down.

Figure 1 displays two other variables in the model; savings and depreciation, to further represent economic growth. The curve labeled investment per worker represents the savings rate of the economy while the straight line represents depreciation ${ }^{28}$, or the proportion of capital that remains intact from one year to the next. Thus, at any level of output, there is a corresponding level of investment as well as depreciation. In this model, the change in capital per worker is given by the difference between investment per worker and depreciation per worker. To the left of the steady state, investment exceeds depreciation leading to an increase in capital per worker and a rightward movement of the output level along the curve "output per worker". To the right of the steady state, depreciation exceeds investment, leading to a decrease in capital per worker and a leftward movement of the output level along the curve "output per worker". When the difference between investment and depreciation is positive, it can be thought of as extra capital in an economy that can be reinvested, however, if the value is to the right of the steady state and is therefore negative, the economy has to pay more for depreciation than it has in its investments. This is the reason for the convergence of the output level to the steady state. The steady state is found at the point where investment and depreciation

${ }^{28}$ Over time, machinery and other forms of capital lose their usefulness by breaking or wearing out. Depreciation is a means of measuring the amount of useful capital within the economy. 
intersect because an economy will move to the steady state if it has extra capital due to investment being larger than depreciation, while an economy cannot remain at a level where depreciation is greater than investment.

While this model was first created to explain European economic growth, it can also be used to represent other nation's growth experience, and is especially helpful in representing why developing nations grow at such fast rates compared to developed nations. The state in which output per worker and capital per worker are Figure 2

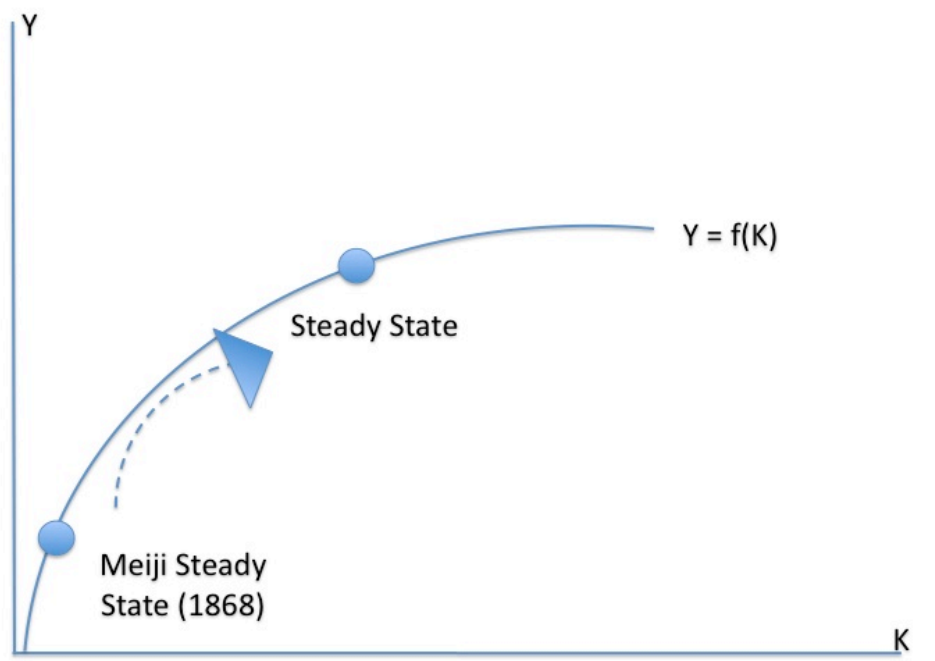

no longer changing is called the steady state. The Solow Growth Model predicts that less developed economies will tend to catch up to income levels of rich countries and converge to the steady state. Hence, the model predicts that poor countries will grow faster than rich countries. As figure 2 shows, Japan, at the beginning of the Meiji era can be placed at a lower level of output. Through the duration of the period, it can be inferred that the Japanese economy began to expand as levels of capital and labor increased. As the theory of the model dictates, increases in capital on the left side of the steady state will lead to increases in the output level. Hence, the Japanese output level moved towards the steady state during the Meiji era as figure 2 illustrates. 
While the output level can be increased through increases in capital and labor, a second means of increasing the output level is through technological innovation, which can be represented as a vertical shift in the function. This is because new technologies improve the economy's productivity levels. This means that technological progress will reduce the amount of labor needed to produce a given amount of output. Another way of saying this is that technological progress increases the output that can be produced with a given amount of labor. This is what creates the vertical shift in the production function when technology is added into the economy. If capital and labor remain constant, new technology creates an increase in output, therefore the output level shifts vertically at the same level of capital per worker.

The variable technology can be thought of as a nation's current state of technological capabilities. Therefore, it cannot be quantified. However, an addition of new technologies will theoretically produce a vertical shift upwards in the function, bringing the output to a higher level. A reduction of technology ${ }^{29}$ will conversely lower the output level with a shift downward. When total output is affected by non-traditional inputs, it is accounted for by the variable "total factor productivity". Anytime economic growth occurs despite no input of capital or labor, total factor productivity is taken as a measure of the growth. Therefore, total factor productivity is evident when technology grows or when economies become more efficient. If a developing nation can get access to technologies outside of their

29 Technological destructions have occurred frequently in world history through events such as China's Cultural Revolution or the genocide of the Khmer Rouge in Cambodia, where intellectuals were purged from the respective countries. 
current knowledge, they gain the ability to either produce new goods, or produce old goods more efficiently. New technology enables workers to discover new methods in order to become more efficient, which can potentially lead to economic growth. This creates a cycle of technological growth leading to economic growth and vice versa. Thus, with technological innovation, high economic growth can be sustained in an economy, however, without technological innovation, economic growth will eventually slow down. These technological advancements have hugely positive economic ramifications ${ }^{30}$ for a nation. In the case of Japan, the importation of technology led to new technologies and new business institutions such as the stock exchange and banks.

As Figure 3 illustrates, in 1868 the Meiji economy was close to the origin due to low levels of capital and savings. Through the period more capital was invested Figure 3

into the

economy, the

Meiji level of

output also

grew, moving

along the

curve. Now, if

no new

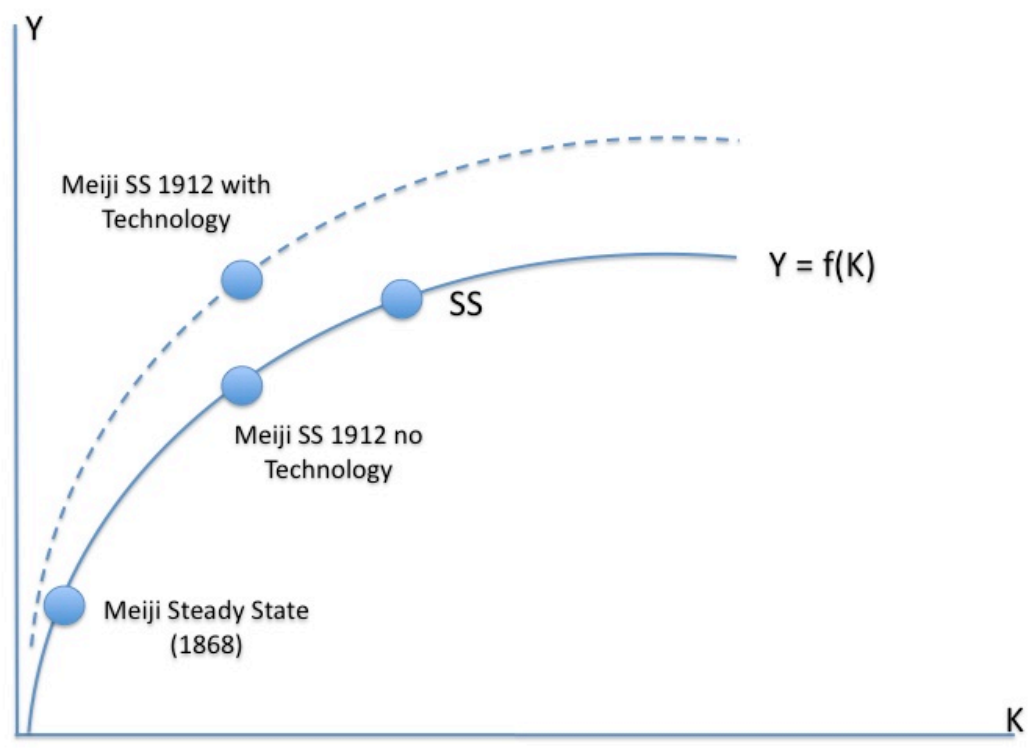

30 Paul Krugman (1994) gives credit to technological advancements when explaining why the world's economies have seen growth in average incomes in the last century. 
technology was introduced to the economy, we would expect the Meiji output level to be somewhere on the original line, closer to the steady state, as represented by the dot in figure 3 labeled "Meiji SS 1912 no technology". But because it is clear that many new technologies were introduced to the Meiji economy, the output function shifts upwards to the dotted line. The output level is at the same point on the $\mathrm{x}$-axis but is now higher, represented by the dot labeled "Meiji SS 1912 with technology". By 1912, new technology had shifted Japan's production function raising their level of production higher than it would have been without new technologies, as figure 3 shows above. Because of technological innovation during the Meiji era, high economic growth was sustained in Japan.

\subsection{The Meiji Era (1868-1912) and the Solow Growth Model}

Since the Meiji Era can be framed with the Solow Growth Model, the increase in capital and labor as well as technology during the period can be examined using the estimations of many scholars ${ }^{31}$. As expected, these estimations will reveal that both capital and labor increased throughout the period. Through discussion of the asset technology in the Meiji era, it will be clear that technological changes and growth occurred in the time period as well. I credit these changes to Tokugawa institutions that affected the Meiji Era economy.

31 Most economic data from 1868 to about 1878 are not available due to the first decade of the Meiji period being unstable with the creation of the new government and insurgency. In this paper, much of the data are for the period of 1878 to 1912. 
The level of capital stock during the Meiji Era grew quite rapidly, more than doubling from $¥ 7,219$ million in 1878 to $¥ 18,810$ million by $1915^{32}$. From 1885 to 1900 , the capital stock grew at $2.2 \%$ in all industries and grew at $5.1 \%$ in nonagricultural industries while the labor rate grew at only .5\% in all industries but grew at $1.5 \%$ in non-agricultural industries. Furthermore, net national product grew at $2.9 \%$ in all industries and at $3.8 \%$ in the non-agricultural industries during this period ${ }^{33}$. While the change in agricultural industries was minimal, nonagricultural industries grew to roughly six times from 1878 to $1915^{34}$. These data indicate Japan's rapid industrialization. During the Meiji era, the size of labor grew at a far slower pace, increasing from 21 million laborers in 1878 to 26 million workers in 1915. However, it should be noted that workers in non-agricultural industries nearly doubled over the period ${ }^{35}$. This was likely due to technological advancements decreasing the number of workers needed in the agricultural sector. The labor surplus that existed by the beginning of the Meiji era enabled workers to find jobs in the industrial sector.

Such economic take-off as the Meiji Japan experience could happen more effectively especially in an economy with a labor surplus in the agricultural sector. In the case of Meiji Japan, improvements in agricultural productivity that occurred in the Tokugawa era created the foundations for the rapid economic growth of the

32 These data are from Table 1.8 of Takafusa Nakamura (p. 12,1983), that was originally compiled Ohkawa (1966), Ohkawa et al (1979), and Umemura (1973). ${ }^{33}$ Nakamura, p.14, Table 1.9: Nakamura's sources for this table are the same as those in table 1.8 .

${ }^{34}$ Ibid, p. 12, Table 1.8: Agricultural industries refer to agriculture, fishery and forestry while non-agricultural industries refer to everything else.

35 Ibid, p. 12, Table 1.8 
Meiji economy ${ }^{36}$. Agricultural techniques such as the use of purchased fertilizer, animal husbandry, foot-pedaled wheels for irrigation and the spread of a number of commercial crops, such as mulberry (silk), indigo, cotton, and tobacco were all introduced during the Tokugawa era ${ }^{37}$. Although agricultural production in the Tokugawa era was not as advanced as the Western nations, compared to other East Asian nations, the Tokugawa farming technology was superior ${ }^{38}$. This led to a strong food supply, which supported the large labor force in the Meiji era.

Capital and labor were not the only contributors to the high economic growth through the Meiji period. The intangible asset of technology also grew in the period. While it is not possible to give a quantitative value for the increase in total factor productivity, Japan's technology did grow throughout the period. In the Tokugawa era, Japan was low-tech but did have some industrial capabilities, such as iron working and weaving, as well as knowledge of some Western science ${ }^{39}$. By the end of the Meiji period, however, Japan's technology had grown substantially, due in large part to the importation of technology from Western nations.

\footnotetext{
${ }^{36}$ For a general paper describing economic effects of agricultural growth see Johnston and Mellor (1961). For information regarding agricultural growth in the Meiji Era see Bassino (2006), Dore (1960), Johnston (1951) and Ohkawa and Rosovsky (1960).

37 Miyamoto, Mataji, Yotaro Sakudo, Yasukichi Yasuba. "Economic Development in Preindustrial Japan, 1859-1894." The Journal of Economic History 25.4 (1965) p. 542 38 ibid p. 544

39 Through Dutch textbooks Japanese "Dutch scholars" were able to learn natural and physical sciences, medicine, astronomy and geography.
} 


\section{Legacy of the Tokugawa Regime and its impact on the Meiji Economy}

Technological advancements that drove the economic growth during the Meiji era derive substantially from the legacy of two social institutions from the Tokugawa era. First, the education system in the Meiji era was basically built upon that of the Tokugawa period and trained a productive labor force that would play large roles in the industrialization of Japan. Second, an outward curiosity with things of the West gave the Meiji leaders an insatiable desire to learn from and impart Western institutions. This affected the Meiji economy through the technology transfer that occurred during the period. As former Tokugawa intellectuals traveled to Western nations in the late 1860's and early 1870's, they brought back with them Western institutions, practices and technologies that added greatly to the economic growth of the Meiji Era.

\subsection{Continuity of the Education system}

The legacy of the Tokugawa regime is seen in Japan's educational system during the Meiji era. Adults who grew up in the strong Tokugawa educational system had been taught in a way that had positive effects on the Meiji society. In the same way, students of the Meiji Era were affected by the strong educational system inherited from the Tokugawa Era. The study of Confucianism in the Tokugawa Era is credited for the skilled adult population in the Meiji era, while the continuation of a strong educational system can also be seen through the high level of literacy, which enabled the workforce in Japan to become better trained to use the new technologies imported from the West. Furthermore, the establishment of higher 
education in Japan paved the way for Japanese intellectuals to gain further understanding of technological advancements and better use them for the profit of the nation.

The educational system of the Tokugawa Era placed emphasis on educating those who belong to the ruling classes such as the samurai, who accounted for only $8 \%$ of the population. Not only were samurai-class people taught military arts they also studied Confucianism. When the Tokugawa family came into power, literacy rates among the samurai class were quite low, but Ieyasu Tokugawa ${ }^{40}$ stressed the importance of raising literacy and education because samurai also took the role of bureaucrats ${ }^{41}$. By the start of the Meiji Era, the number of schools had grown from about 100 schools to the size of over 12,000 schools, both for upper class and lowerclass citizens ${ }^{42}$. The Meiji government essentially inherited the Tokugawa education system because many schools were already established and families had adapted to the weekly school schedules. When the Ministry of Education was formed in 1871 and elementary school became compulsory shortly after, ${ }^{43}$ the Japanese already had a large educational infrastructure and were well prepared to educate Meiji era students.

Thanks to the Tokugawa education system, Meiji Japan had a high literacy rate $^{44}$. This not only gave Japan a skilled workforce of common-class citizens, but also produced many intellectuals. The Meiji government, having disbanded the

${ }^{40}$ Ieyasu Tokugawa was the first Tokugawa Shogun, coming into power in 1603. ${ }^{41}$ Pyle, 1996 p. 32

42 ibid, p. 89

43 ibid, p. 91

${ }^{44}$ Scholars agree that in 1868, Japan had literacy rates even with and above many Western nations. 
samurai class along with the entire caste system, gained a labor force of welleducated former samurai ${ }^{45}$. Because of their high literacy rates and some experience in bureaucracy within their domains, many samurai were able to take on governmental roles in their former domains ${ }^{46}$. The commoners of Japan had access to terakoya, or local schools, which provided rudimentary education in reading, writing and arithmetic ${ }^{47}$. Thus a high literacy rate was produced, which also increased the Japanese ability to use and access the new technologies being imported into the nation by Westerners ${ }^{48}$.

Tokugawa intellectuals such as Yukichi Fukuzawa played a large role in developing the Meiji Era education system. One reason why intellectuals such as Fukuzawa advocated for a better, modern system of education was their distaste of the education system in their own era ${ }^{49}$. Fukuzawa himself founded Keio University. Shibusawa Eiichi is another example of a Meiji leader who was educated primarily with Confucianism but who embraced and introduced Western knowledge. Eiichi believed that "economic progress cannot be achieved by simply aiming for personal gain and the prosperity of commerce and industry, unless it is based on the strong foundation of morality. There is no other way but to fall back on the practice of the

\footnotetext{
${ }^{45}$ Because of the peace that characterized the Tokugawa Era, the younger generation of samurai had become more of a societal symbol than a warrior. Because of this, they had increased time to study Confucianism and did this diligently, unlike Western elites who spent much of their time at social gatherings. ${ }^{46}$ For more on the samurai rehabilitation policy of the Meiji Era see Harootunian (1960).

${ }^{47}$ Ibid, p. 89

48 Dore, Ronald P. Education in Tokugawa Japan. New York: Columbia University Press, 1965. p. 323

${ }^{49}$ Pyle, 1996. p. 88
} 
principle of the union of economics and morality, if we desire human progress"50.

Eiichi's Confucian background led him to selflessly work towards the progress of the nation, not just his own economic standing.

The Meiji government also focused on developing a higher education system. Upon completion of the compulsory elementary schooling, many options for higher learning were available. By 1905, a tenth of the eligible population had enrolled in schools of higher learning51. In the Meiji education system, schools were comprised of middle schools or, "normal schools," to teach students to become teachers, vocational and technical schools specializing in industrial fields, and other private and public higher schools ${ }^{52}$ for students seeking further education after middle school. The addition of higher education began to nurture an already literate workforce and gave women the opportunity to gain an education, something that was globally uncommon at the time. Trade schools, where students learned a single trade, were equally important to the growing industries of Japan as they began to create workers who knew how to use machinery and were familiar with concepts of engineering and science. The industrial growth during the Meiji Era simply could not have occurred without the contributions of the trade schools in the Meiji Era.

The Meiji Era continuation of strong educational systems was a great strength of the nation. Because the foundations for modern education had been created during the Tokugawa era, the Meiji education system was able to yield

\footnotetext{
50 Hoover, 1978 p. 292

51 Gordon, 2009. p. 104

52 These higher schools also taught young women. In fact, the government mandated that every prefecture would have at least one women-only higher school in 1899. Christian missionaries also founded several higher schools for women during the period. ibid p. 104
} 
productive labor. Compulsory education created a highly literate population while higher learning formed a competent workforce. Because of this, Japan was able to use a large labor force, due to the labor surplus from the agricultural sector, which was also a highly productive labor force, all of which aided Japan in its industrialization and high economic growth during the period.

\subsection{Continuity of Outward Curiosity with the West}

The second legacy of the Tokugawa Era I will examine is the outward curiosity that Japanese had with things of the West. Tokugawa Japan was secluded from most of the outside world and the first relations with Western countries were negative. Despite this, the Japanese had a great curiosity with the Western world during the Tokugawa era. As Japan opened up to international trade, it paved the way to a technology transfer.

The main force behind the Meiji Restoration was xenophobia, Japan's fear of

Westerners colonizing their country. This xenophobia led to the Meiji government's Figure 4

\begin{tabular}{|c|c|c|}
\hline Source & Organization & Year Initiated \\
\hline \multirow[t]{4}{*}{ Britain } & Navy & 1869 \\
\hline & Telograph system & 1869 \\
\hline & Postal system & 1872 \\
\hline & Postal savings system & 1875 \\
\hline \multirow[t]{5}{*}{ France } & Army & 1869 \\
\hline & Primary school system & 1872 \\
\hline & Tokyo Ketsiti-che (police) & 1874 \\
\hline & Judicial system & 1872 \\
\hline & Kempeitai (military police) & 1881 \\
\hline \multirow{3}{*}{ United States } & "Primury school system" & 1809 \\
\hline & National bank system & $18 \pi 2$ \\
\hline & Sapporo Agricultural College & 1879 \\
\hline Germany & Army & 1878 \\
\hline Belgium & Bank of Japan & 1882 \\
\hline
\end{tabular}

dichotomous view of the West.

Paradoxically, Japan

sought to prevent

Western invasion and

remove foreign

influences by importing

Western technology. 
Japan aggressively absorbed Western technology to strengthen the nation and westernize the nation to ward off an invasion. Through the Meiji era, as Westerners came into Japan and Japanese went out, many institutions and technologies were imported into Japan ${ }^{53}$, as figure 4 shows above. This technology transfer that occurred increased total factor productivity in Japan, leading to increased economic output and rapid growth in the Meiji era.

During the Meiji Era, the intrigue with Western culture thrived as changes occurred in many social contexts. For men, dress transitioned from traditional Japanese garb to the European style suit and shoes replaced geta (wooden clogs) ${ }^{54}$. Western style was imported in many facets of society from military practices to $\operatorname{art}^{55}$. A sort of "western fever" quickly overtook Japan, but it wasn't simply limited to importing goods and ideologies. The Meiji Period also saw an importation of technology and economic institutions from Japanese diplomats as well as foreign visitors.

Japan also began to send delegations to foreign countries for diplomatic reasons, as well as students to study in foreign nations. These trips were beneficial to the nation as Japanese bureaucrats were able to gain valuable knowledge of Western institutions and practices. The Iwakura Mission ${ }^{56}$, occurring from 18711873, sent over a dozen Japanese delegates to the United States and Europe to

${ }^{53}$ See figure 4 for several institutions that were imported from Western nations. Pyle, 1996. p. 79

${ }^{54}$ Durant, Will. Our Oriental Heritage. New York, Simon and Schuster, 1954.

${ }^{55}$ Gordon, 2009. pp. 106-7

56 The main purpose of the Iwakura Mission, which was to correct the unequal treaties that Japan faced, was not successful. However, during their time abroad the Japanese delegates saw the need to make themselves look "more Western" in order to benefit foreign delegations. 
observe Western culture ${ }^{57}$ and is often considered the most important foreign endeavor of the Meiji government. While the Japanese delegates were able to see many Western factories, buildings and mines, what really struck them was the disparity between Western militaries and their own. The pursuit of a strong military became one cause of increased industrial activity as Japan began to build military necessities ${ }^{58}$. While the Iwakura Mission's legacy may be militarily based, in general the Japanese diplomatic missions enabled the Japanese to learn more about Western nations and technologies.

On these diplomatic missions, Tokugawa era intellectuals learned of several institutions that they introduced to Japan in the Meiji period. Many of these institutions would have positive economic effects such as the establishment of a national bank. As stated above, the fact that Tokugawa men had any affect on the Meiji era is remarkable. Usually when a new regime takes power, those supportive of the old regime are purged, however, the Meiji government was pragmatic in its acceptance of Tokugawa Era intellectuals, and this acceptance would have a great effect on Japan. Two Tokugawa intellectuals who affected the Meiji era economic growth are important to discuss: Shibusawa Eiichi and Yukichi Fukuzawa. Both Eiichi and Fukuzawa were men who worked for the Tokugawa government and were supportive of it through the transition to the Meiji government. For this reason, it is even more surprising that they would both be founding fathers of Japan.

Shibusawa Eiichi (born in 1840) was a Tokugawa Era intellectual trained in the Confucian classics that, like many of the intellectuals of the time, detested the

57 Gordon, 2009. p. 73

58 Pyle, 1996. p. 99 
class system of Japan ${ }^{59}$. Despite Eiichi's aversion to the social structure of Japan, he eventually found himself working for the Tokugawa, a job that would end up taking him to Europe as a delegation member. In early 1867 he travelled to Europe and said:

I am decidedly anti-foreign, but without knowledge of foreign matters. I am now of the opinion that one should know matters at first hand before he opposes or criticizes them. Moreover, I believe that there are many things, which we should learn from foreign countries. From this point of view, I am pleased to accept the appointment ${ }^{60}$.

While skeptical of the West, this trip to Europe convinced Eiichi that industry and commerce were the source of wealth and power for a nation. On his trip, Eiichi noted four Western institutions he deemed valuable. First, he saw the high status of businessmen. This surprised him due to the low status merchants had in Japan. Second, he saw the advantage of a joint-stock corporate form of organization. Third, he noted European stock exchanges and banks and the strong financial systems of Europe. Finally, Eiichi noticed the philanthropy practiced by European businessmen ${ }^{61}$. The visit to Europe was especially important to Eiichi who saw the importance of international trade. During the years following his return to Japan, he formed the first national bank of Japan and helped organize around 250 industrial

${ }^{59}$ Hoover, William D. "Shibusawa Eiichi." Great Historical Figures of Japan. Eds. Hyoe Murakami, and Thomas J. Harper. Tokyo, Japan Cultural Institute, 1978. pp. 284-5

${ }^{60}$ Hoover, 1978. p. 287

61 ibid p. 288 
and commercial enterprises ${ }^{62}$. Eiichi's contributions to Japan's financial sector were crucial to the advancement of the nation economically.

While Yukichi Fukuzawa did not have as grand an impact on Japan's economy as that of Shibusawa Eiichi, Fukuzawa was an important figure in the Meiji Era because of his intercultural experiences in Western nations, which led him to seek positive change in Japan. Like Eiichi, Fukuzawa was unhappy with the Japanese class system. In his autobiography he wrote:

The thing that made me most unhappy in Nakatsu63 was the restriction of rank and position. Not only on official occasions, but in private intercourse, and even among children, the distinctions between high and low were clearly defined. Children of lower samurai families like ours were obliged to use a respectful manner of address in speaking to the children of high samurai families, while these children used an arrogant form to address us ${ }^{64}$. Likely due to his dislike of the class system, Fukuzawa went on to study Dutch, the only foreign language officially permitted to study in Japan at the time. Later, Fukuzawa would visit America and Europe, always buying as many foreign books as

62 ibid 1978 p. 291 In his business endeavors, Eiichi was extremely philanthropic, saying that his goal was to "straighten out the chaotic Japanese business system, develop it, and bring respectability to the businessman. Never for a moment did I aim at my own profitability." His attitude reflected his learning in the Confucian Analects which he regularly applied to his business practices. Eiichi's philanthropy could be paralleled to Andrew Carnegie in the later years of his life.

${ }^{63}$ Nakatsu was Yukichi Fukuzawa's mother's feudal province. Upon the death of Fukuzawa's father in Osaka, his family moved to Nakatsu, where Fukuzawa's mother had grown up.

${ }^{64}$ Fukuzawa, Yukichi. The Autobiography of Yukichi Fukuzawa. First American Edition. New York: Columbia University Press, 1966. p. 18 
he could ${ }^{65}$. Fukuzawa's fascination with the West would lead him on to have a substantial influence on Japan's education system, the topic discussed above.

Japanese intrigue with the West also brought about a great technology transfer to Japan as both Westerners, and Japanese who had studied abroad, brought Western technologies and methods into the nation. Japanese weaving ${ }^{66}$ is one example of an industry that drastically changed during the Meiji Era due to the importation of Western technology. Also, Japanese and British cooperation at the Takashima coal mine is another example of Western method being imported into Japan.

Through the era of transition from Tokugawa to Meiji, the Japanese weaving industry became one of the most developed industries in the country ${ }^{67}$. While without Western technology weaving had become quite prosperous, the addition of new technologies didn't stifle growth in the industry. Rather, items such as the power loom and synthetic dyes gave the Japanese weaving industry higher productivity, reduced costs and more colorful products ${ }^{68}$. Through the beginning of the Meiji period, large amounts of British looms and machinery were imported into Japan to satisfy the growth in the industry ${ }^{69}$. Because of the continued success of the weaving industry in Japan, technical schools were created in order to teach

\footnotetext{
65 Fukuzawa, 1966. p. 171

${ }^{66}$ For more on the Meiji Era weaving industry see Choi, 2011, Choi, 2009 and Hashino and Kurosawa, 2011.

${ }^{67}$ Hashino, Tomoko. "Institutionalising Technical Education: The Case of Weaving Districts in Meiji Japan." Austrailian Economic History Review 52.1 (2012) p. 26 68 ibid. p. 27

${ }^{69}$ Choi, Eugene K. “Entrepreneurial Leadership in the Meiji Cotton Spinners' Early Conceptualisation of Global Competition." Business History 51.6 (2009) p. 931
} 
trade skills to prospective workers ${ }^{70}$. Because of the importation of Western technology, the weaving industry in Japan grew substantially over the course of the Meiji era and gave Japan an exportable good, which was exported with great success in East Asia ${ }^{71}$.

This was also the case of the Takashima coal mine, ${ }^{72}$ where Western method was imported into Japan through a collaborated effort between British and Japanese coal miners. When Nabeshima Naomasa, Prince of Hizen, began planning a mining project at Takashima, he did not have sufficient knowledge of mining to undergo the digging so he turned to the British for help ${ }^{73}$. While the project was not without hardship, the mine found success in producing coal. More importantly, the mine was eventually passed on into Japanese management, ${ }^{74}$ finalizing the transfer of mining competence and method to the Japanese. Japan became able to mine its own coal and became a leading exporter of coal of East Asia, marking the overall success of the Takashima collaboration ${ }^{75}$.

Japan's outward curiosity with the West during the Tokugawa Era continued on into the Meiji Era with positive results. The Japanese became students of the West by learning Western languages, which gave them knowledge of Western sciences and practices and created trade opportunities with Western nations. The

\footnotetext{
${ }^{70}$ Hashino, 2012. pp. 29-30

71 Saxonhouse, Gary R. "How Japan First Began to Export Machine-Made Manufactures to East Asia." The Japanese Economic Review 56.4 (2005) p. 431

72 The Takashima coal mine was excavated in 1868-9 on a small island near Nagasaki. See Checkland, 1984.

73 Checkland, Olive and Sydney. "British and Japanese Economic Interaction Under the Early Meiji: The Takashima Coal Mine 1868-88." Business History 26.2 (1984) pp. 139-140

74 Mitsubishi took control over the mine in 1881. Checkland, 1984. p. 151

75 Checkland, 1984. p. 152
} 
effect of this was a technology transfer and increased total factor productivity, which gave Japan an advantage economically compared to its East Asian neighbors. As Western institutions, practices and technologies began to fall in place, Japan was able to create higher quality goods that could be exported to East Asia as well as Europe and the United States.

\section{Conclusion}

Japan's high economic growth during the Meiji era is a product of many variables, from industrial growth to international trade. However, the unconscious contributions of the Tokugawa regime to the Meiji economy are often overlooked. This essay has shown that through the legacies of the Tokugawa education system and outward curiosity with the West, the high economic growth of the Meiji era was made possible. The strong education system constructed in the Tokugawa era produced a competent workforce that would be used throughout the entire Meiji era, while curiosity with the West produced multilingual Japanese who were able to conduct business on an international basis and bring strong institutions, such as banks and stock markets, back to Japan in order to strengthen the nation's business sector. Because of the Meiji government's choice to utilize Tokugawa institutions rather than destroy them, an old regime was able to help new economic growth. 


\section{References}

Bassino, Jean-Pascal. "The Growth of Agricultural Output and Food Supply in Meiji Japan: Economic Miracle or Statistical Artifact?" Economic Development and Cultural Change 54.2 (2006): 503-520. Print.

Checkland, Olive and Sydney. "British and Japanese Economic Interaction Under the Early Meiji: The Takashima Coal Mine 1868-88." Business History 26.2 (1984): 139-155.

Choi, Eugene K. "Entrepreneurial Leadership in the Meiji Cotton Spinners' Early Conceptualisation of Global Competition." Business History 51.6 (2009): 927958. Print.

Choi, Eugene K. "Another Spinning Innovation: The Case of the Rattling Spindle, Garabo, in the Development of the Japanese Spinning Industry." Australian Economic History Review 51.1 (2011): 22-45. Print.

Crawcour, Sydney. "The Tokugawa Period and Japan's Preparation for Modern Economic Growth." Journal of Japanese Studies 1.1 (1974): 113-125. Print. Department of Commerce (U.S.). Historical Statistics of the United States, 1976. Dore, Ronald P. "Agricultural Improvement in Japan: 1870-1900." Economic Development and Cultural Change 9.1 (1960): 69-91. Print.

Dore, Ronald P. Education in Tokugawa Japan. New York: Columbia University Press, 1965. 
Durant, Will. Our Oriental Heritage. New York, Simon and Schuster, 1954. Print.

Flath, David. The Japanese Economy. $2^{\text {nd }}$ ed. Oxford, NY, Oxford University Press, 2005

Fukuzawa, Yukichi. The Autobiography of Yukichi Fukuzawa. First American Edition. New York: Columbia University Press, 1966. Print.

Gordon, Andrew. A Modern History of Japan: From Tokugawa Times to the Present. 2nd ed. New York, Oxford University Press, 2009. Print.

Harootunian, Harry D. "The Economic Rehabilitation of the Samurai in the Early Meiji Period." The Journal of Asian Studies 19.4 (1960): 433-444. Print.

Hashino, Tomoko. "Institutionalising Technical Education: The Case of Weaving Districts in Meiji Japan." Australian Economic History Review 52.1 (2012): 2542. Print.

Hashino, Tomoko, and Takafumi Kurosawa. "Beyond Marshallian Agglomeration Economies: The Role of the Local Trade Association in a Meiji Japan Weaving District (1868-1912)." Kobe University Library (2011): 1-34. Web. 16 Dec. 2012. <http://www.lib.kobe-u.ac.jp/repository/81003323.pdf>.

Hoover, William D. "Shibusawa Eiichi." Great Historical Figures of Japan. Eds. Hyoe Murakami, and Thomas J. Harper. Tokyo, Japan Cultural Institute, 1978. 284292. Print.

Ito, Takatoshi. The Japanese Economy. 5th. Cambridge, MA: MIT Press, 1992. Print. Johnston, Bruce. "Agricultural Productivity and Economic Development in Japan." Journal of Political Economy 59.6 (1951): 498-513. Print. 
Johnston, Bruce F, John W. Mellor. "The Role of Agriculture in Economic Development." The American Economic Review 51.4 (1961): 566-593. Print. Krugman, Paul. "The Myth of Asia's Miracle." Foreign Affairs 73.6 (1994): 62-78. Print.

Kuznets, Simon. The Economic Growth of Nations. Harvard University Press, 1971. McCormick, Ken. Veblen in Plain English, Youngstown, New York, Cambria Press, 2006.

Metzler, Mark. Lever of Empire: The International Gold Standard and the Crisis of Liberalism in Prewar Japan. Berkeley: CA, University of California Press, 2006. Mitchell, B.R. European Historical Statistics. McMillan, 1975.

Miyamoto, Mataji, Yotaro Sakudo, Yasukichi Yasuba. "Economic Development in Preindustrial Japan, 1859-1894." The Journal of Economic History 25.4 (1965): 541-564. Print.

Nakamura, Takafusa. Economic Growth in Prewar Japan., New York, Yale University Press, 1983.

Ohkawa, Kazushi. Analysis of the Japanese Economy. Shunjusha, 1962.

Ohkawa, Kazushi et al. Shihon Sutokku (The Capital Stock). Toyo Keizai Shimp Sha, 1966 (LTES 3).

Ohkawa Kazushi, Henry Rosovsky. Japanese Economic Growth: Trend Acceleration in the Twentieth Century, Stanford, 1973.

Ohkawa, Kazushi, Henry Rosovsky. "The Role of Agriculture in Modern Japanese Economic Development." Economic Development and Cultural Change 9.1 (1960): 43-67. Print. 
Ohkawa, Kazushi and Shinohara, Miyohei with Larry Meissner. Patterns of Japanese Economic Development: A Quantitative Appraisal. Yale University press, 1979. Ohkawa, Kazushi; Takamatsu, Nobukiyo; and Yamamoto, Yuzo. National Income. Toyo Keizai Shimpo Sha, 1974.

Pyle, Kenneth B. The Making of Modern Japan. 2nd e. Lexington, MA: D.C. Heath and Company, 1996. Print.

Rostow, W.W. The Stages of Economic Growth, (New York, 1990)

Saxonhouse, Gary R. "How Japan First Began to Export Machine-Made Manufactures to East Asia." The Japanese Economic Review 56.4 (2005): 431-440. Print.

Sharpe, M.E. Nation Building: The Meiji Era 1868-1912, The Japanese Economy (July/October 2002)

Toru, Haga and Masakazu Yamazaki. "Reexamining the Era of National Seclusion," Japan Echo 19 (winter 1992), 73-75.

Umemura, Mataji. "Sangyo Betsu Koyo no Hendo: 1880-1980" (Changes in Employment by Industry). In Keizai Kenkyu, vol. 24, no. 2, 1973, pp. 107-13. Veblen, Thorstein. Imperial Germany. New York, Augustus M. Kelley, 1915. Yamamura, Kozo. "Success Illgotten? The Role of Meiji Militarism in Japan's Technological Progress." The Journal of Economic History 37.1 (1977): 113135. Print. 